\title{
Systematic review of potential causes of intraocular lens opacification
}

J oaquín Fernández PhD, ${ }^{1,2}$ Alicia Sánchez-García MSc, 1,3 Manuel Rodríguez-Vallejo $\mathrm{PhD}^{1}$ and David P. Piñero $\mathrm{PhD}^{3,4}$

1Department of Ophthalmology (Qvision), Vithas Virgen del Mar Hospital, 04120, Almería, Spain

2Department of Ophthalmology, Torrecárdenas Hospital Complex, 04009, Almería, Spain

${ }^{3}$ Department of Optics, Pharmacology and Anatomy, University of Alicante, Alicante, Spain

${ }^{4}$ Department of Ophthalmology, Vithas Medimar International Hospital, Alicante, Spain

Correspondence: David P. Piñero, Department of Optics, Pharmacology and Anatomy, University of Alicante, Crta San Vicente del Raspeig s/n 03016, San

Vicente del Raspeig, Alicante, Spain

e-mail: david.pinyero@ua.es

Short running title: Quality of research on IOL opacification

Received 8 May 2019; accepted 21 September 2019

Funding sources / Financial disclosure: The author David P Piñero was supported by the Ministry of Economy, Industry and Competitiveness of Spain within the programme Ramón y Cajal, RYC-2016-20471. 
Conflict of interest: Dr. Fernández is a consultant to Medicontur Medical Engineering Ltd. Inc., Zsámbék, Hungary. The remaining authors declare nothing to disclose. 


\section{Abstract}

Intraocular lens (IOL) opacification is an infrequent complication of cataract surgery. Surface analysis has demonstrated that the opacification of IOLs is related to calcium or phosphate precipitation on or within the lenses, but the associated mechanisms are unknown, and the scientific literature is heterogeneous and limited to case series and retrospective studies. The purpose of this systematic review was to analyse the most frequent conditions associated with opacification of IOLS reported by studies. A search was carried out using the PubMed MEDLINE, Web of Science (WOS) and Scopus databases. The quality of the studies selected was evaluated using the Pierson tool. The search provided a total of 811 articles, of which 39 were selected following the inclusion and exclusion criteria. The most common opacified lenses were hydrophilic IOLs according to our analysis. The mean time of appearance of lens opacification was $14.93 \pm 17.82$ months. The most frequent conditions associated with opacification of the IOLs were Descemet Stripping with Automated Endothelial Keratoplasty (DSAEK/DSEK) and diabetes mellitus (DM), followed by pars plana vitrectomy (PPV), blood hypertension (HT), and glaucoma. Concerning the quality analysis, the mean score was $7.00 \pm 1.43$ (scoring range from 0 to 10 ), indicating an acceptable quality of the case reports and retrospective studies. In conclusion, DSAEK / DSEK, DM, PPV, glaucoma and hypertension are conditions with potential risk of IOL opacification after cataract surgery, especially when implanting hydrophilic acrylic IOLs.

Keywords: intraocular lens, IOL opacification, IOL explantation, cataract surgery, acrylic IOL 


\section{I NTRODUCTION}

Intraocular lens (IOL) explantation after cataract surgery is a rare condition but is sometimes necessary. The incidence of explantation IOL is $7.7 \%$ according to a population-based retrospective data analysis. ${ }^{1}$ In 2012, an observational multicentre retrospective study was conducted to retrieve all data from cases in which IOL explantation was performed in 15 different ophthalmological centers. ${ }^{2} \mathrm{~A}$ total of 257 explanted pseudophakic IOLs were reported, with the main causes of IOL explantation being dislocation/decentration (56.3\%), incorrect lens power (12.8\%), neuroadaptation failure $(6.2 \%)$, pseudophakic bullous keratopathy $(2.3 \%)$ and endophthalmitis (1.9\%). These authors concluded that IOL opacification was the third most frequent reason for IOL explantation (11.3\%). ${ }^{2}$

The causes of opacification have been explored, and factors that might be associated with it include conditions associated with the patient, IOL manufacturer, IOL storage, surgical techniques and adjuvants. ${ }^{3}$ Histopathological, histochemical, electron microscopic, elemental and molecular surface analytical techniques have demonstrated that the opacification of IOLs is related to calcium and phosphate precipitation on or within the lenses in PMMA, silicon and hydrophilic acrylic IOLs. In relation to the opacification of hydrophobic lenses, only two cases have been reported in which the opacification of lenses spontaneously occurred in a reversible way. ${ }^{4}$

Some causes and mechanisms associated with the accumulation of deposits on IOLs have been investigated in in-vitro studies. Drimtzias et $\mathrm{al}^{5}$ suggested that IOL calcification is caused by nucleation and crystal growth of calcium phosphates on the IOL surface, with this process starting in the lens interior. However, there are no studies that explain how this process occurs in vivo. In addition, the scientific literature is heterogeneous with regard the conditions associated with IOL opacification, with most of it being based on case series and retrospective studies, 
providing low levels of scientific evidence. Furthermore, there are no reviews summarizing the types of conditions associated with IOL opacification. For this reason, a systematic review was performed aimed at analysing the quality of studies on IOL opacification according to the level of scientific evidence found to define the most frequent conditions associated with IOL opacification.

\section{METHODS}

A systematic review was carried out with a bibliographic search focused on answering the question, "What are the causes of opacification of intraocular lenses?" The search was made using the following databases: PubMed MEDLINE, Web of Science (WOS) and Scopus (all databases).

The search was limited to studies published from 2010 to 2019. The inclusion criterion was that articles must be original articles reporting cases of $\mathrm{IOL}$ opacification, including cases of IOL calcification. They could be descriptive studies, with sample populations including all ages, from children to adults. Studies whose main objective was not to describe the lens opacification were excluded. Likewise, studies about expert guidelines or opinions, non-original articles and studies in a language other than English were excluded. The search equation used in this review was as follows:

(opacification OR "loss of transparenc*" OR transparenc*) AND ("intraocular lens" OR IOL OR pseudophakic) NOT/AND NOT ("posterior capsul* opacification”)

Case series and retrospective studies are uncontrolled study designs with an increased risk of bias. However, these studies must present an internal validity that must be evaluated. For such a purpose, the Pierson tool was used. This tool is an approach for evaluating the validity of case reports based on five components: 
documentation, uniqueness, objectivity, interpretation and educational value. ${ }^{6}$ It provides a score ranging from 0 to 10. A score between 9 and 10 means that the report is likely to be a worthwhile contribution to the literature. A score between 6 and 8 means that the reader should be cautious about the validity and clinical value of the report. A score of less than 5 means that the report is of insufficient quality for publication. In the current systematic review, the mean, standard deviation (SD), maximum and minimum values of the Pierson scores were calculated.

The search was carried out on February 4, 2019. For the elaboration of the flow chart and the data collection process, the guidelines of the PRISMA (Preferred Reporting Items for Systematic Reviews and Meta-Analyses) declaration were followed. ${ }^{7}$ Figure 1 shows the flow chart followed during the search. Using the search equation, a total of 811 articles was found. After removing duplicates, 294 studies were found. Following the inclusion and exclusion criteria, 45 articles were initially selected for a more comprehensive study and to confirm inclusion. Of the 45 articles, 5 did not fulfil the inclusion criteria and were excluded from further analysis. The remaining included articles numbered 40 and were analysed using the Pierson tool. ${ }^{8-48}$

\section{RESULTS}

Table 1 contains the main characteristics of each of the studies reviewed. The sample size, the type of IOL implanted and the time of occurrence and causes of lens opacification are displayed. The most common opacified lenses were hydrophilic IOLs according to our analysis. Specifically, lens opacification was reported in 82 cases implanted with different Oculentis IOL models, 7 cases implanted with the Akreos Adapt IOL (Bausch \& Lomb), 6 cases implanted with the C-Flex 570C IOL (Rayner Intraocular Lenses Ltd.) and 5 with the Akreos MI60 (Bausch \& Lomb). In 2 of the 39 reviewed studies, a hydrophobic lens was implanted. In one of these two 
studies, the authors stated that opacification of the lens was spontaneously reversed at 5 weeks after its detection.

Concerning the time of appearance of lens opacification with respect to the last intervention administered to the patient, the mean value was $14.93 \pm 17.82$ months, ranging from a maximum time of 72 months to a minimum time of 10 minutes. There was great heterogeneity in the time of appearance of opacification, regardless of the intervention.

Figure 2 shows the frequency of the conditions associated with the opacification of the IOLS, considering that the total number of eyes showing IOL opacification in the reviewed articles was 245. The most frequent condition associated with opacification of the IOLs was Descemet Stripping with Automated Endothelial Keratoplasty (DSAEK/DSEK), which was reported in 70/245 eyes. This was followed by diabetes mellitus (DM) and pars plana vitrectomy (PPV), which were reported in 37/245 and 30/245 eyes, respectively. Arterial hypertension (HT) and glaucoma were reported in 26/245 and 15/245 eyes, respectively. Likewise, combined conditions were reported in 24/245 eyes, including combinations of DM, HT, glaucoma and different surgical procedures, as has been detailed in Table 1.

The results of the quality analysis of each study included in the review are summarized in Table 2. The mean score was $7.00 \pm 1.43$, with a maximum score of 9 and a minimum of 5 . Seven of the thirty-nine studies got the minimum score, and eight studies got the maximum. The best evaluated item was interpretation, which refers to how the results were interpreted and how the conclusions of the study were reached. On the other hand, the item with the worst score was uniqueness, which evaluates whether the case presented was unique or a case with the same characteristics was previously presented.

One of the main reasons leading to a poor evaluation was lack of information about the implanted lens or how phacoemulsification was performed. In 9 of the 39 
studies, the name and characteristics of the opacified lens were not described by the authors.

\section{DISCUSSION}

In this systematic review, posterior lamellar keratoplasty (DSAEK/DSEK) and diabetes mellitus (DM) were the most frequently reported conditions associated with opacification of IOLs according to the included studies. Other causes, such as pars plana vitrectomy (PPV), glaucoma and arterial hypertension (HT), also had high reporting rates. The exact mechanism leading to IOL opacification in all cases was not clear, but in DSAEK / DSEK, it is believed to be due to repeated exposure to intracameral injections of air or gas and elevated intraocular pressure (IOP). ${ }^{23,44}$ The aetiology in the case of DM may be the disruption of the blood-aqueous barrier and the proinflammatory condition. It should be noted that protein deposits have also been detected on the surface of explanted polymethyl methacrylate and hydrophilic acrylic lenses and are more intense in the presence of blood-aqueous barrier (BAB) disruption. ${ }^{28}$ Patients with diabetic retinopathy typically have high aqueous humour calcium concentrations, which may contribute to the opacification. ${ }^{31}$

In relation to PPV, either combined with phacoemulsification or alone, it is postulated that intracameral gas could contribute to the calcification of the surface of the IOL. ${ }^{29,36}$ Although the exact mechanism of calcification is under investigation, one hypothesis is that local damage to the hydrophilic IOL surface due to direct contact with air/gas at the exposed area may lead to $\mathrm{Ca} / \mathrm{P}$ deposition from the aqueous humour. ${ }^{44,46}$ In glaucoma, the hypothesis is that the presence of calcium deposits in aqueous humour is related to changes in aqueous humour $\mathrm{pH}$ after glaucoma surgery, since opacification was described mainly in conjunction with surgical procedures for glaucoma, such as iridotomies, trabeculectomies or Ex-PRESS shunt implantation. ${ }^{32,40,41}$ On the other hand, a combination of the previously 
mentioned techniques (DSAEK/DSEK and PPV) can increase the possibilities of IOL opacification, as is the case of combining an intervention of DSAEK in a patient with diabetes or glaucoma, or PPV in patients with arterial hypertension. ${ }^{4,13,31,39,42}$

Another factor that may increase the risk of IOL surface opacification is the type of material. Most of the included studies employed hydrophilic acrylic lenses, and, in their conclusions, they discouraged the use of this type of lens when carrying out the aforementioned interventions. ${ }^{37,45,47}$ In this review, we evaluated whether the different characteristics of the lenses used could be a factor that could influence lens opacification. However, detailed information about the chemical composition of the polymer of each hydrophilic opacified IOL was not provided in the revised studies, with only a report of the percentage of water content, which was in the range of $25-26 \%$ in all cases. Regarding hydrophobic lenses, they were used in only 2 studies, in one of which the opacification turned out to be reversible without the need of explantation of the lens. ${ }^{4,34}$ The mechanisms by which the opacification was resolved are unknown. However, this fact should be considered when implanting hydrophobic lenses along with another advantage, which is the lower incidence of posterior capsule opacification compared to hydrophilic lenses. ${ }^{49,50}$

Quality analysis of the included studies showed that most of the studies had good methodology and internal validity, although no study reached the maximum score, mainly because they were not original works. This finding shows that opacification of lenses was reported on numerous occasions, although the maximum level of evidence was found in retrospective studies and case series. There were no studies with several cohorts or control groups. It should be considered that these types of studies would be ethically controversial, since the experimental group would receive an implant with a greater possibility of explantation due to potential IOL opacification.

Another reason why the evaluated studies did not achieve a high score with the Pierson tool was the lack of data in their methodology or results, such as the 
type of lens implanted or how the cataract surgery was carried out.9,10,20,21,25,29,35 These pieces of information are very relevant and should be considered, as differences in the polymers with which they are made may be crucial for a better understanding of the exact mechanisms of opacification. Likewise, several studies did not specify how the phacoemulsification was carried out, even though the surgical procedure of cataract extraction may be one factor contributing to the process of IOL opacification. This is especially true in those case reports on IOL opacification after DSAEK / DSEK, which were focused on the description of the corneal surgical procedure, but minimal information was provided on the cataract surgery.

One of the strengths of this study is that it is the first systematic review to analyse the main causes of opacification of reported IOLs. However, the main limitation is that this review was carried out on studies with a low level of evidence. ${ }^{51}$ Another limitation was the temporal limitations of this systematic review. Arbitrarily, 2010 was defined as the cutoff year for the search, considering that the most recent articles would include more complete information about the conditions associated with IOL opacification due to the enhanced clinical protocols and the advanced technology that clinical researchers have adopted in the last few years.

In conclusion, the main conditions associated with IOL opacification according to published studies are DSAEK / DSEK, DM, PPV, glaucoma and hypertension. These conditions should be given importance in order to avoid the explantation of intraocular lenses by deposits on its surface, especially if they are hydrophilic acrylic lenses. Studies with a greater degree of evidence on this topic are needed in order to better understand the mechanisms of deposition accumulation on or within intraocular lenses and thus how to avoid them. 


\section{REFERENCES}

1. Szigiato A-A, Schlenker MB, Ahmed IIK. Population-based analysis of intraocular lens exchange and repositioning. J Cataract Refract Surg. 2017;43(6): 754-60.

2. Fernández-Buenaga R, Alió JL. Intraocular Lens Explantation After Cataract Surgery: Indications, Results, and Explantation Techniques. Asia-Pacific J Ophthalmol (Philadelphia, Pa). 2017;6(4):372-80.

3. Werner L. Opacification and degradation of the implanted intraocular lenses. In: Biomaterials and Regenerative Medicine in Ophthalmology. Elsevier; 2016. p. $419-42$.

4. Kim DJ, Chuck RS, Lee JK, Park CY. Reversible opacification of hydrophobic acrylic intraocular lens-two cases report. BMC Ophthalmol. 2017;17(1):111.

5. Drimtzias EG, Rokidi SG, Gartaganis SP, Koutsoukos PG. Experimental investigation on mechanism of hydrophilic acrylic intraocular lens calcification. AmJ Ophthalmol. 2011;152(5):824-33.e1.

6. Pierson DJ. How to read a case report (or teaching case of the month). Respir Care. 2009;54(10): 1372-8.

7. Moher D, Liberati A, Tetzlaff J, Altman DG, PRISMA Group. Preferred reporting items for systematic reviews and meta-analyses: the PRISMA statement. PLoS Med. 2009;6(7):e1000097.

8. Patryn E, Van Der Meulen IJ E, Lapid-Gortzak R, Mourits M, Nieuwendaal CP. Intraocular lens opacifications in descemet stripping endothelial keratoplasty patients. Cornea. 2012;31(10):1189-92.

9. Ma S-T, Yang C-M, Hou Y-C. Postoperative intraocular lens opacification. Taiwan J Ophthalmol. 2018;8(1):49-51.

10. Choudhry S, Goel N, Mehta A, Mahajan N. Anterior segment optical coherence tomography of intraocular lens opacification. Indian J Ophthalmol. 
2018;66(6):858-60.

11. Liu Q, Zhang S, Wang X, Cao W, Jia Y. Acute clouding of trifocal lens during implantation: a case report. BMC Ophthalmol. 2017;17(1):242.

12. Ahad MA, Darcy K, Cook SD, Tole DM. Intraocular lens opacification after descemet stripping automated endothelial keratoplasty. Cornea. 2014;33(12): 1307-11.

13. Park CY, Chuck RS. Reversible opacification of a hydrophilic acrylic intraocular lens. J Cataract Refract Surg. 2012;38(1):166-9.

14. Lim AKE, Goh PP, Azura R, Mariam I. Opacification of Acriflex 50CSE hydrophilic acrylic intraocular lenses. J Cataract Refract Surg. 2011;37(4):6559.

15. Park JC, Habib NE, Moate RM. Intraocular lens opacification after corneal endothelial keratoplasty: Electron microscopy and x-ray element spectroscopy analysis. J Cataract Refract Surg. 2015;41(1):140-5.

16. Rahimi M, Azimi A, Hosseinzadeh M. Intraocular lens calcification: Clinicopathological report of two cases and literature review. J Ophthalmic Vis Res. 2018; 13(2):195-9.

17. Verdaguer P, Gris O, Casaroli-Marano RP, Elies D, Muñoz-Gutierrez G, Güell J L. Intraocular Lens Opacification after Endothelial Keratoplasty as Analyzed by Environmental Scanning Electron Microscopy. Cornea. 2015;34(8):972-5.

18. Khan MI, Muhtaseb M. Opacification of the intraocular lens implant following uneventful Descemet's stripping endothelial keratoplasty. Contact Lens Anterior Eye. 2011;34(2):92-3.

19. Park D II, Ha SW, Park SB, Lew H. Hydrophilic acrylic intraocular lens optic opacification in a diabetic patient. J pn J Ophthalmol. 2011;55(6):595-9.

20. Khurana RN, Werner L. Calcification of a Hydrophilic Acrylic Intraocular Lens After Pars Plana Vitrectomy. Retin Cases Brief Rep. 2018;12(3):204-6.

21. Mhéalóid ÁN, Fulcher T, O'Keefe M. Anterior surface opacification of 
intraocular lenses after Descemet's stripping automated endothelial keratoplasty. BMJ Case Rep. 2015;2015.

22. Pehere NK, Bojja S, Vemuganti GK, Vaddavalli PK, Samant M, Jalali S, et al. Opacification of intraocular lenses implanted during infancy: A clinicopathologic study of 4 explanted intraocular lenses. Ophthalmology. 2011;118(11):2128-2132.e1.

23. Fellman MA, Werner L, Liu ET, Stallings S, Floyd AM, Van Der Meulen IJE, et al. Calcification of a hydrophilic acrylic intraocular lens after Descemetstripping endothelial keratoplasty: Case report and laboratory analyses. J Cataract Refract Surg. 2013;39(5): 799-803.

24. Morgan-Warren PJ, Andreatta W, Patel AK. Opacification of hydrophilic intraocular lenses after Descemet stripping automated endothelial keratoplasty. Clin Ophthalmol. 2015;9:277-83.

25. Quigley C, McElnea E, Fahy G. Trends in corneal transplant surgery in I reland: indications and outcomes of corneal transplant surgery and intraocular lens opacification following Descemet's stripping automated endothelial keratoplasty. Ir J Med Sci. 2018;187(1):231-6.

26. Fung SSM, Sykakis E, Islam NM, Zambarakji HJ, Khoramnia R, Auffarth GU, et al. Intraocular lens opacification following intracameral injection of recombinant tissue plasminogen activator to treat inflammatory membranes after cataract surgery. J Ophthalmol. 2015;2015.

27. Graffi S, Leon P, Nahum Y, Gutfreund S, Spena R, Mattioli L, et al. Outcomes of ultrathin Descemet stripping automated endothelial keratoplasty (UTDSAEK) performed in eyes with failure of primary Descemet membrane endothelial keratoplasty (DMEK). $\mathrm{Br} J$ Ophthalmol. 2018 May 29. pii: bjophthalmol-2017-311834. doi: 10.1136/bjophthalmol-2017-311834. [Epub ahead of print].

28. Daigle P, Carbonneau M. Opacification of the C-flex 570C intraocular lens after 
sulcus fixation. Int Ophthalmol. 2018;38(4):1783-6.

29. Marcovich AL, Tandogan T, Bareket M, Eting E, Kaplan-Ashiri I, Bukelman A, et al. Opacification of hydrophilic intraocular lenses associated with vitrectomy and injection of intraocular gas. BMJ Open Ophthalmol. 2018;3(1):e000157.

30. Cavallini GM, Volante V, Campi L, De Maria M, Fornasari E, Urso G. Postoperative diffuse opacification of a hydrophilic acrylic intraocular lens: analysis of an explant. Int Ophthalmol. 2018;38(4):1733-9.

31. Lee SJ, Choi JH, Sun HJ , Choi KS, Jung GY. Surface calcification of hydrophilic acrylic intraocular lens related to inflammatory membrane formation after combined vitrectomy and cataract surgery. J Cataract Refract Surg. 2010;36(4):676-81.

32. Agresta A, Giudiceandrea A, Salgarello T, Manganelli C, Fasciani R, Caporossi A. Influence of aqueous humor convection current on IOL opacification. Int Ophthalmol. 2017;37(6):1337-9.

33. Yildirim TM, Auffarth GU, Łabuz G, Bopp S, Son HS, Khoramnia R. Material Analysis and Optical Quality Assessment of Opacified Hydrophilic Acrylic Intraocular Lenses After Pars Plana Vitrectomy. Am J Ophthalmol. 2018; 193: 10-9.

34. Schrittenlocher S, Penier M, Schaub F, Bock F, Cursiefen C, Bachmann B. Intraocular Lens Calcifications After (Triple-) Descemet Membrane Endothelial Keratoplasty. Am J Ophthalmol. 2017;179:129-36.

35. Giers BC, Tandogan T, Auffarth GU, Choi CY, Auerbach FN, Sel S, et al. Hydrophilic intraocular lens opacification after posterior lamellar keratoplasty a material analysis with special reference to optical quality assessment. BMC Ophthalmol. 2017;17(1):150.

36. Kalevar A, Dollin M, Gupta RR. Opacification of Scleral-Sutured Akreos Ao60 Intraocular Lens After Vitrectomy With Gas Tamponade: Case Series. Retin Cases Brief Rep. 2017 Sep 27. doi: 10.1097/ICB.0000000000000634. [Epub 
ahead of print].

37. Mojzis $P$, Studeny $P$, Werner L, Piñero DP. Late opacification of a hydrophilic acrylic intraocular lens in Europe. Eur J Ophthalmol. 2016;26(2):e24-6.

38. Bompastor-Ramos P, Póvoa J, Lobo C, Rodriguez AE, Alió J L, Werner L, et al. Late postoperative opacification of a hydrophilic-hydrophobic acrylic intraocular lens. J Cataract Refract Surg. 2016;42(9): 1324-31.

39. Norouzpour A, Zarei-Ghanavati S. Hydrophilic acrylic intraocular lens opacification after descemet stripping automated endothelial keratoplasty. J Ophthalmic Vis Res. 2016;11(2):225-7.

40. Forlini M, Dell'Aversana Orabona G, Bratu Al, Rossini P, Cavallini GM, Forlini C. Akreos adapt AO intraocular lens opacification: A case report. Case Rep Ophthalmol. 2013;4(3):151-4.

41. Abdul-Rahman A, House P, Richards J. Intraocular lens dystrophic calcification after trans-scleral diode laser treatment for a cyclodialysis cleft. Am J Ophthalmol Case Reports. 2018;11: 78-83.

42. Dhital A, Spalton DJ, Goyal S, Werner L. Calcification in hydrophilic intraocular lenses associated with injection of intraocular gas. Am J Ophthalmol. 2012; 153(6): 1154-60.

43. Nieuwendaal CP, Van Der Meulen IJ E, Patryn EK, Werner L, Mourits MP, LapidGortzak R. Opacification of the intraocular lens after descemet stripping endothelial keratoplasty. Cornea. 2015;34(11):1375-7.

44. Werner L, Wilbanks G, Nieuwendaal CP, Dhital A, Waite A, Schmidinger G, et al. Localized opacification of hydrophilic acrylic intraocular lenses after procedures using intracameral injection of air or gas. J Cataract Refract Surg. 2015;41(1): 199-207.

45. Mojzis $P$, Studeny $P$, Werner L, Piñero DP. Opacification of a hydrophilic acrylic intraocular lens with a hydrophobic surface after air injection in Descemetstripping automated endothelial keratoplasty in a patient with Fuchs 
dystrophy. J Cataract Refract Surg. 2016;42(3):485-8.

46. MacLean KD, Apel A, Wilson J, Werner L. Calcification of hydrophilic acrylic intraocular lenses associated with intracameral air injection following DMEK. J Cataract Refract Surg. 2015;41(6):1310-4.

47. Gurabardhi $M$, Häberle $H$, Aurich $H$, Werner $L$, Pham DT. Serial intraocular lens opacifications of different designs from the same manufacturer: Clinical and light microscopic results of 71 explant cases. J Cataract Refract Surg. 2018;44(11):1326-1332.

48. Turner A, House P. Proliferation of lens epithelial cells on the Acrysof intraocular lens: clinical and histological features of a case. Clin Experiment Ophthalmol. 2001;29(6):426-8.

49. Zhao Y, Yang K, Li J, Huang Y, Zhu S. Comparison of hydrophobic and hydrophilic intraocular lens in preventing posterior capsule opacification after cataract surgery: An updated meta-analysis. Medicine (Baltimore). 2017;96(44):e8301.

50. Li Y, Wang J, Chen Z, Tang X. Effect of hydrophobic acrylic versus hydrophilic acrylic intraocular lens on posterior capsule opacification: Meta-analysis. PLoS One. 2013;8(11).

51. Murad MH, Asi N, Alsawas M, Alahdab F. New evidence pyramid. Evid Based Med. 2016;21(4):125-7.

\section{FIGURE LEGENDS}

Figure 1: Flow chart of the selection process of relevant articles that were included in the systematic review for further quality analysis.

Figure 2: Bar diagram of the conditions associated with lens opacification reported in each study. DSAEK, Descemet Stripping with Automated Endothelial Keratoplasty; DSEK, Descemet's Stripping Endothelial Keratoplasty; DMEK, Descemet Membrane 
Endothelial Keratoplasty; PPV, Pars plana vitrectomy; DM, Diabetes Mellitus; HT, hypertension 


\section{TABLES}

Table 1: Main characteristics of the 40 included studies

\begin{tabular}{|c|c|c|c|c|}
\hline $\begin{array}{l}\text { Author } \\
\text { (year) }\end{array}$ & $N$ & Type of IOL & $\begin{array}{l}\text { Time of } \\
\text { occurrence } \\
\text { of Lens } \\
\text { Opacification }\end{array}$ & $\begin{array}{l}\text { Conditions } \\
\text { associated } \\
\text { with Lens } \\
\text { Opacification }\end{array}$ \\
\hline Lee S/ (2010) & 2 & $\begin{array}{l}\text { Hydrophilic C-Flex } \\
570 \mathrm{C}\end{array}$ & 6 months & $\begin{array}{l}\text { PPV, DM } 1 \\
\text { case, PPV } 1 \\
\text { case }\end{array}$ \\
\hline Khan M (2011) & 1 & $\begin{array}{l}\text { Hydrophilic Centerflex } \\
570 \mathrm{H}\end{array}$ & 9 months & DSAEK \\
\hline Park DI (2011) & 1 & $\begin{array}{l}\text { Hydrophilic Akreos MI- } \\
60\end{array}$ & 6 months & $\begin{array}{l}\text { DM, PPV, } \\
\text { glaucoma }\end{array}$ \\
\hline $\begin{array}{l}\text { Pehere N } \\
\text { (2011) }\end{array}$ & 4 & $\begin{array}{l}\text { Hydrophilic Akreos MI- } \\
60 \text { and SQRYCF }\end{array}$ & $\begin{array}{l}4 \text { months-1 } \\
\text { year }\end{array}$ & PPV \\
\hline $\operatorname{Lim} A K(2011)$ & 14 & $\begin{array}{l}\text { Hydrophilic AcriFlex } \\
\text { 50CSE }\end{array}$ & 1 year & DM \\
\hline $\begin{array}{l}\text { Park CY } \\
\text { (2012) }\end{array}$ & 1 & $\begin{array}{l}\text { Hydrophilic Akreos MI- } \\
60\end{array}$ & 1 month & $\begin{array}{l}\text { DM, anti-VEGF } \\
\text { intravitreal } \\
\text { injection }\end{array}$ \\
\hline $\begin{array}{l}\text { Dhital A } \\
\text { (2012) }\end{array}$ & 3 & $\begin{array}{l}\text { Hydrophilic C-Flex } \\
570 C \text { and Akreos } \\
\text { Adapt }\end{array}$ & $\begin{array}{l}6 \text { weeks-1 } \\
\text { year }\end{array}$ & $\begin{array}{l}\text { PPV, DM, } \\
\text { intravitreal } \\
\text { injection, } \\
\text { DSAEK, HT }\end{array}$ \\
\hline $\begin{array}{l}\text { Patryn E } \\
\text { (2012) }\end{array}$ & 3 & Hydrophilic acrylic & $\begin{array}{l}18 \text { weks-1 } \\
\text { year }\end{array}$ & $\begin{array}{l}\text { DSEK + DM + } \\
\text { HT } 1 \text { case, } \\
\text { DSEK } 2 \text { cases }\end{array}$ \\
\hline $\begin{array}{l}\text { Fellman MA } \\
\text { (2013) }\end{array}$ & 1 & Hydrophilic acrylic & 2 years & DSEK \\
\hline $\begin{array}{l}\text { Forlini M } \\
\text { (2013) }\end{array}$ & 1 & $\begin{array}{l}\text { Hydrophilic Akreos } \\
\text { Adapt }\end{array}$ & 1 year & $\begin{array}{l}\text { DM, HT, } \\
\text { transscleral } \\
\text { drainage }\end{array}$ \\
\hline $\begin{array}{l}\text { Ahad MA } \\
\text { (2014) }\end{array}$ & 15 & $\begin{array}{l}\text { Hydrophilic Akreos } \\
\text { Adapt, C-Flex 570C }\end{array}$ & 17 months & DSAEK \\
\hline $\begin{array}{l}\text { Fung SS } \\
\text { (2015) }\end{array}$ & 7 & $\begin{array}{l}\text { Hydrophilic C-Flex } \\
570 \mathrm{C} \text { and Rayner } \\
\text { Superflex } 620 \mathrm{H}\end{array}$ & 6 months & $\begin{array}{l}\text { N/A } 3 \text { cases, } \\
\text { glaucoma } 1 \\
\text { case, DM + PPV } \\
2 \text { cases, DM } 1\end{array}$ \\
\hline
\end{tabular}




\begin{tabular}{|c|c|c|c|c|}
\hline & & & & cas \\
\hline $\begin{array}{l}\text { Verdaguer } P \\
\text { (2015) }\end{array}$ & 1 & $\begin{array}{l}\text { Hydrophilic Akreos } \\
\text { Adapt }\end{array}$ & 1 year & DSAEK \\
\hline $\begin{array}{l}\text { Werner L } \\
\text { (2015) }\end{array}$ & 7 & Hydrophilic acrylic & 6 months & DSAEK, DSEK \\
\hline $\begin{array}{l}\text { Ní Mhéalóid Á } \\
\text { (2015) }\end{array}$ & 4 & $\begin{array}{l}\text { Hydrophilic Akreos } \\
\text { Adapt and hydrophilic } \\
\text { with hydrophobic } \\
\text { surface CT Asphina }\end{array}$ & $\begin{array}{l}7 \text { months-2 } \\
\text { years }\end{array}$ & DSAEK \\
\hline Park JC (2015) & 5 & $\begin{array}{l}\text { Hydrophilic Stabibag, } \\
\text { Lenstec LH 3000, } \\
\text { MI } 60\end{array}$ & 4 mont-1 year & DSAEK \\
\hline $\begin{array}{l}\text { Nieuwendaal C } \\
\text { (2015) }\end{array}$ & 8 & $\begin{array}{l}\text { Hydrophilic } 3 \text { Stabibag } \\
\text { Zeiss, } 3 \text { Rayner } 620 \mathrm{H}, \\
2 \text { Akreos } 160\end{array}$ & $1-2$ years & DSAEK \\
\hline $\begin{array}{l}\text { Morgan- } \\
\text { Warren PJ } \\
\text { (2015) }\end{array}$ & 6 & Hydrophilic acrylic & 32 months & DSAEK \\
\hline $\begin{array}{l}\text { Mojzis P } \\
\text { (2016a) }\end{array}$ & 1 & Hydrophilic CT47S & 8 months & DSAEK \\
\hline $\begin{array}{l}\text { Bompastor- } \\
\text { Ramos P } \\
\text { (2016) }\end{array}$ & 19 & $\begin{array}{l}\text { Hydrophilic with } \\
\text { hydrophobic surface } \\
\text { Lentis LS-502-1 }\end{array}$ & $1-2$ years & $\begin{array}{l}\text { DM, glaucoma, } \\
\text { epiretinal } \\
\text { membrane }\end{array}$ \\
\hline $\begin{array}{l}\text { Norouzpour A } \\
\text { (2016) }\end{array}$ & 1 & $\begin{array}{l}\text { Hydrophilic Akreos } \\
\text { Adapt }\end{array}$ & 10 months & $\begin{array}{l}\text { Glaucoma, } \\
\text { DSAEK }\end{array}$ \\
\hline $\begin{array}{l}\text { Mojzis P } \\
\text { (2016b) }\end{array}$ & 2 & Hydrophilic I oflex & 5 years & $\begin{array}{l}\mathrm{DM}+\mathrm{AMD}+ \\
\text { HT } 1 \text { case, HT } 1 \\
\text { case }\end{array}$ \\
\hline $\begin{array}{l}\text { Kalevar A } \\
\text { (2017) }\end{array}$ & 2 & $\begin{array}{l}\text { Hydrophilic Akreos } \\
\text { AO60 }\end{array}$ & 5-6 months & PPV \\
\hline $\begin{array}{l}\text { Giers BC } \\
\text { (2017) }\end{array}$ & 13 & Hydrophilic acrylic & $\begin{array}{l}6 \text { months-2 } \\
\text { years }\end{array}$ & DSAEK, DSEK \\
\hline $\begin{array}{l}\text { Schrittenlocher } \\
\text { S (2017) }\end{array}$ & 14 & $\begin{array}{l}\text { Hydrophilic (11), } \\
\text { hydrophobic (2), } \\
\text { Hydrophilic with } \\
\text { hydrophobic surface } \\
\text { (1) }\end{array}$ & 6 months & Triple DMEK \\
\hline $\operatorname{Liu} Q$ (2017) & 1 & $\begin{array}{l}\text { Hydrophilic with } \\
\text { hydrophobic surface } \\
\text { AT LISA tri 839mp }\end{array}$ & 10 minutes & $\begin{array}{l}\text { Fluctuation of } \\
\text { temperature }\end{array}$ \\
\hline Kim DJ (2017) & 2 & $\begin{array}{l}\text { Hydrophobic Tecnis } \\
\text { ZCB00 }\end{array}$ & $\begin{array}{l}7 \text { weeks (it } \\
\text { was resolved }\end{array}$ & $\begin{array}{l}\text { DM + Glaucoma } \\
1 \text { case, N/A } 1\end{array}$ \\
\hline
\end{tabular}




\begin{tabular}{|c|c|c|c|c|}
\hline & & & at 5 weeks) & case \\
\hline $\begin{array}{l}\text { Agresta A } \\
\text { (2017) }\end{array}$ & 1 & $\begin{array}{l}\text { Hydrophilic Akreos } \\
\text { Adapt }\end{array}$ & 10 months & $\begin{array}{l}\text { Glaucoma, } \\
\text { iridotomy and } \\
\text { Ex-PRESS shunt }\end{array}$ \\
\hline $\begin{array}{l}\text { Abdul-Rahman } \\
\text { A (2018) }\end{array}$ & 1 & $\begin{array}{l}\text { Hydrophilic Akreos } \\
\text { M160L }\end{array}$ & 4 months & $\begin{array}{l}\text { DM, glaucoma, } \\
\text { trabeculectomy }\end{array}$ \\
\hline $\begin{array}{l}\text { Yildirim TM } \\
\text { (2018) }\end{array}$ & 10 & $\begin{array}{l}\text { Hydrophilic CT } \\
\text { Asphina 409M, Basis Z } \\
\text { B1AW00, C-flex } \\
\text { Aspheric 970C }\end{array}$ & 1 year & PPV \\
\hline $\begin{array}{l}\text { Cavallini GM } \\
\text { (2018) }\end{array}$ & 1 & $\begin{array}{l}\text { Hydrophilic Lentis L- } \\
313\end{array}$ & 2 years & $\mathrm{N} / \mathrm{A}$ \\
\hline $\begin{array}{l}\text { Marcovich AL } \\
\text { (2018) }\end{array}$ & 11 & $\begin{array}{l}\text { Hydrophilic Hanita B } \\
\text { lens, Xcellence Idea, } \\
\text { Biotech vision care } \\
\text { Eyecryl, Rayner } \\
\text { Superflex Aspheric } \\
\text { 920, M-flex 630F, CT } \\
\text { Asphina 409M, C-flex } \\
\text { Aspheric 570C }\end{array}$ & $\begin{array}{l}1 \text { month-6 } \\
\text { years }\end{array}$ & PPV \\
\hline $\begin{array}{l}\text { Daigle P } \\
\text { (2018) }\end{array}$ & 1 & $\begin{array}{l}\text { Hydrophilic C-Flex } \\
570 C\end{array}$ & 5 years & $\begin{array}{l}\text { DM, breakdown } \\
\text { of the blood- } \\
\text { aqueous barrier }\end{array}$ \\
\hline Graffi S (2018) & 4 & Hydrophilic acrylic & 6 months & DSAEK, DMEK \\
\hline $\begin{array}{l}\text { Choudhry S et } \\
\text { al. (2018) }\end{array}$ & 1 & Hydrophilic AcrySof & During surgery & DM \\
\hline $\begin{array}{l}\text { Quigley C } \\
\text { (2018) }\end{array}$ & 1 & Hydrophilic acrylic & $\mathrm{N} / \mathrm{A}$ & $\begin{array}{l}\text { DSAEK, } \\
\text { glaucoma }\end{array}$ \\
\hline $\begin{array}{l}\text { Khurana RN } \\
\text { (2018) }\end{array}$ & 1 & $\begin{array}{l}\text { Hydrophilic } \\
\text { NaturaLens }\end{array}$ & 8 months & PPV, DM \\
\hline Ma ST (2018) & 2 & $\begin{array}{l}\text { Hydrophilic AcrySof } \\
\text { SA60AT }\end{array}$ & 9 months & $\begin{array}{l}\text { DSAEK } 1 \text { case, } \\
\text { DM + PPV + } \\
\text { Silicone oil } \\
\text { tamponade + } \\
\text { Intravitreal air } \\
\text { injection } 1 \text { case }\end{array}$ \\
\hline $\begin{array}{l}\text { Rahimi M } \\
\text { (2018) }\end{array}$ & 2 & Hydrophilic acrylic & 1-4 years & $\begin{array}{l}\mathrm{DM}+\mathrm{PPV} 1 \\
\text { case, PPV } 1 \\
\text { case }\end{array}$ \\
\hline $\begin{array}{l}\text { Gurabardhi M } \\
\text { (2018) }\end{array}$ & 71 & $\begin{array}{l}\text { Hydrophilic LS-412-1Y, } \\
\text { LS-502-1, LS-402-1Y, } \\
\text { LS-313-1Y, L-402, L- }\end{array}$ & 50 months & $\begin{array}{l}\text { HT } 25 \text { cases, } \\
\text { HT + DM } 2 \\
\text { cases, DM } 10\end{array}$ \\
\hline
\end{tabular}


cases, HT +

Renal failure 2

cases, Renal

failure 4 cases,

$\mathrm{HT}+\mathrm{DM}+$

AMD +

Glaucoma 2

cases, HT + DM

+ Glaucoma 2

cases, PPV +

Gas tamponade

1 cases, DSAEK

1 case, AMD 11

cases,

Glaucoma 9

cases, Anterior

uveítis 2 cases

PPV, Pars plana vitrectomy; DSAEK, Descemet Stripping with Automated Endothelial Keratoplasty; DSEK, Descemet's Stripping Endothelial Keratoplasty; DM, Diabetes Mellitus; HT, hypertension; anti-VEGF, anti-vascular endothelial growth factor; DMEK, Descemet Membrane Endothelial Keratoplasty; N/A, Not Available 
Table 2: Outcomes of the quality analysis with the Pierson tool of the articles included in the review

\begin{tabular}{|c|c|c|c|c|c|c|}
\hline $\begin{array}{l}\text { Author } \\
\text { (year) }\end{array}$ & Documentation & Uniqueness & $\begin{array}{l}\text { Educational } \\
\text { Value }\end{array}$ & Objectivity & I nterpretation & $\begin{array}{l}\text { OUTCOME } \\
(\mathrm{X} / \mathrm{10})\end{array}$ \\
\hline Lee SJ (2010) & 2 & 2 & 1 & 1 & 2 & 8 \\
\hline Khan M (2011) & 2 & 1 & 2 & 1 & 2 & 8 \\
\hline Park DI (2011) & 2 & 1 & 1 & 1 & 2 & 7 \\
\hline $\begin{array}{l}\text { Pehere N } \\
(2011)\end{array}$ & 2 & 1 & 2 & 1 & 2 & 8 \\
\hline Lim AK (2011) & 2 & 1 & 2 & 2 & 2 & 9 \\
\hline $\begin{array}{l}\text { Park CY } \\
\text { (2012) }\end{array}$ & 2 & 2 & 2 & 2 & 1 & 9 \\
\hline $\begin{array}{l}\text { Dhital A } \\
\text { (2012) }\end{array}$ & 2 & 1 & 1 & 2 & 2 & 8 \\
\hline $\begin{array}{l}\text { Patryn E } \\
\text { (2012) }\end{array}$ & 1 & 1 & 1 & 1 & 2 & 6 \\
\hline $\begin{array}{l}\text { Fellman MA } \\
\text { (2013) }\end{array}$ & 2 & 0 & 1 & 1 & 1 & 5 \\
\hline $\begin{array}{l}\text { Forlini M } \\
\text { (2013) }\end{array}$ & 2 & 1 & 1 & 2 & 2 & 8 \\
\hline $\begin{array}{l}\text { Ahad MA } \\
\text { (2014) }\end{array}$ & 1 & 0 & 1 & 2 & 2 & 6 \\
\hline $\begin{array}{l}\text { Fung SS } \\
\text { (2015) }\end{array}$ & 2 & 2 & 1 & 2 & 2 & 9 \\
\hline
\end{tabular}




\begin{tabular}{l|llllll}
$\begin{array}{l}\text { Verdaguer P } \\
(2015)\end{array}$ & 2 & 1 & 1 & 2 & 1 & $\mathbf{7}$ \\
$\begin{array}{l}\text { Werner L } \\
(2015)\end{array}$ & 1 & 0 & 1 & 2 & 2 & $\mathbf{6}$ \\
$\begin{array}{l}\text { Ní Mhéalóid Á } \\
(2015)\end{array}$ & 2 & 1 & 2 & 2 & 2 & $\mathbf{9}$ \\
$\begin{array}{l}\text { Park JC (2015) } \\
\text { Nieuwendaal C } \\
(2015)\end{array}$ & 2 & 0 & 1 & 2 & 2 & $\mathbf{7}$ \\
$\begin{array}{l}\text { Morgan- } \\
\text { Warren PJ }\end{array}$ & 2 & 0 & 1 & 2 & 2 & $\mathbf{7}$ \\
$\begin{array}{l}2015) \\
\text { Mojzis P }\end{array}$ & 1 & 0 & 1 & 2 & 2 & $\mathbf{6}$ \\
$\begin{array}{l}(2016 a) \\
\text { Bompastor- }\end{array}$ & 2 & 0 & 1 & 2 & 2 & $\mathbf{7}$ \\
$\begin{array}{l}\text { Ramos P } \\
(2016)\end{array}$ & 2 & 1 & 2 & 2 & 2 & $\mathbf{9}$ \\
$\begin{array}{l}\text { Norouzpour A } \\
(2016)\end{array}$ & 2 & 1 & 1 & 2 & 2 & $\mathbf{8}$ \\
$\begin{array}{l}\text { Mojzis P } \\
(2016 b)\end{array}$ & 2 & 0 & 1 & 1 & 2 & $\mathbf{6}$ \\
$\begin{array}{l}\text { Kalevar A } \\
(2017)\end{array}$ & 2 & 1 & 1 & 1 & 1 & $\mathbf{6}$ \\
$\begin{array}{l}\text { Giers BC } \\
(2017)\end{array}$ & 1 & 0 & 1 & 1 & 2 & $\mathbf{5}$
\end{tabular}




\begin{tabular}{|c|c|c|c|c|c|c|}
\hline \multirow{4}{*}{$\begin{array}{l}\text { Schrittenlocher } \\
\text { S (2017) } \\
\text { Liu Q (2017) } \\
\text { Kim DJ (2017) } \\
\text { Agresta A } \\
\text { (2017) }\end{array}$} & 2 & 1 & 1 & 2 & 2 & 8 \\
\hline & 2 & 2 & 1 & 2 & 2 & 9 \\
\hline & 1 & 2 & 2 & 2 & 2 & 9 \\
\hline & 2 & 1 & 1 & 2 & 1 & 7 \\
\hline \multirow{2}{*}{$\begin{array}{l}\text { Abdul-Rahman } \\
\text { A (2018) } \\
\text { Yildirim TM } \\
\text { (2018) }\end{array}$} & 2 & 2 & 1 & 2 & 2 & 9 \\
\hline & 1 & 1 & 1 & 2 & 2 & 7 \\
\hline \multirow{3}{*}{$\begin{array}{l}\text { Cavallini GM } \\
\text { (2018) } \\
\text { Marcovich AL } \\
\text { (2018) } \\
\text { Daigle P } \\
\text { (2018) }\end{array}$} & 1 & 1 & 1 & 1 & 2 & 6 \\
\hline & 1 & 0 & 1 & 1 & 2 & 5 \\
\hline & 2 & 1 & 2 & 1 & 2 & 8 \\
\hline \multirow{6}{*}{$\begin{array}{l}\text { Graffi S (2018) } \\
\text { Choudhry S et } \\
\text { al. (2018) } \\
\text { Quigley C } \\
\text { (2018) } \\
\text { Khurana RN } \\
\text { (2018) } \\
\text { Ma ST (2018) } \\
\text { Rahimi M }\end{array}$} & 1 & 1 & 1 & 1 & 2 & 6 \\
\hline & 1 & 1 & 1 & 1 & 1 & 5 \\
\hline & 1 & 0 & 1 & 1 & 2 & 5 \\
\hline & 1 & 0 & 1 & 1 & 2 & 5 \\
\hline & 1 & 0 & 1 & 1 & 2 & 5 \\
\hline & 1 & 1 & 1 & 1 & 2 & 6 \\
\hline
\end{tabular}


(2018)

This article is protected by copyright. All rights reserved. 


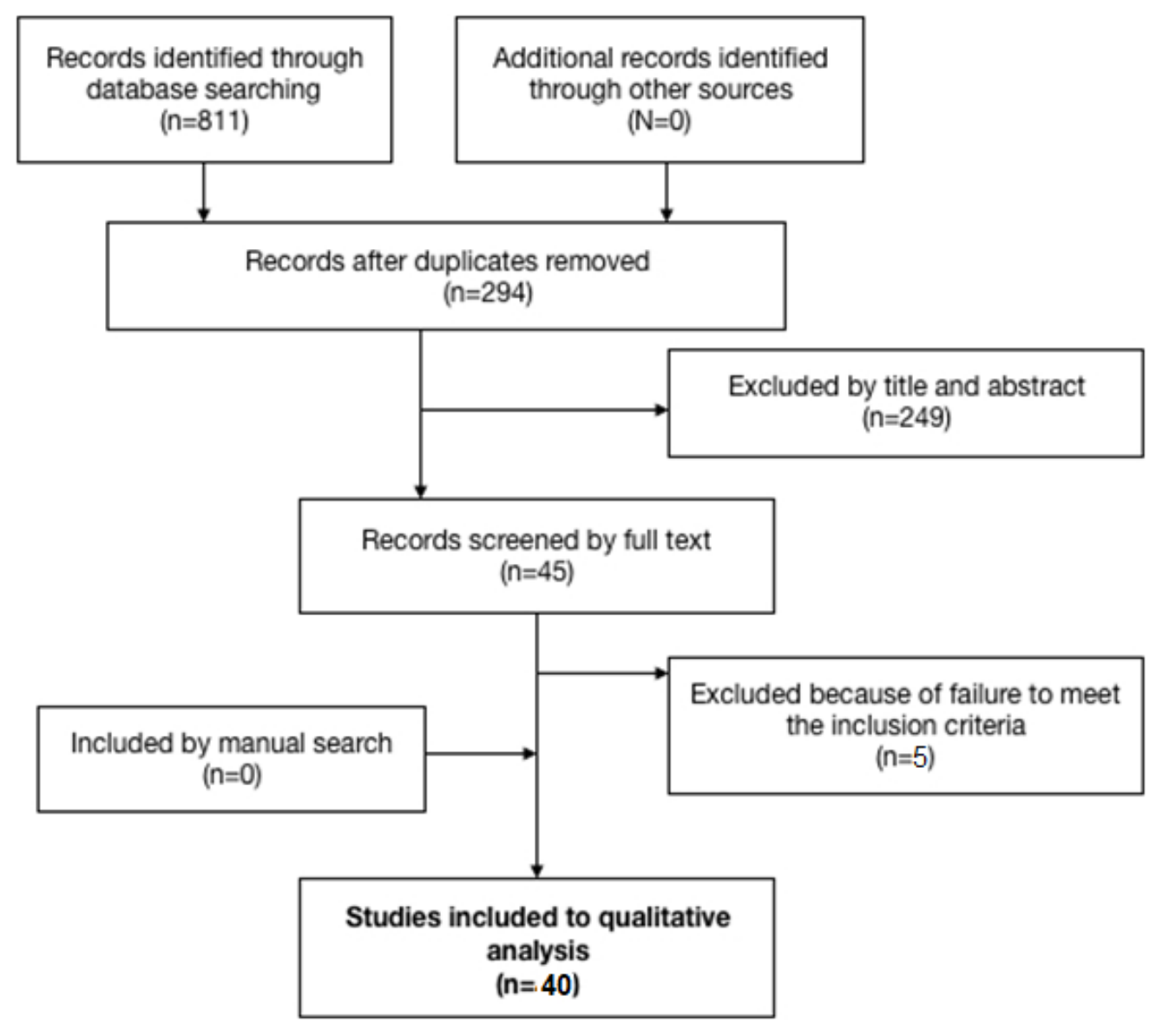

This article is protected by copyright. All rights reserved. 


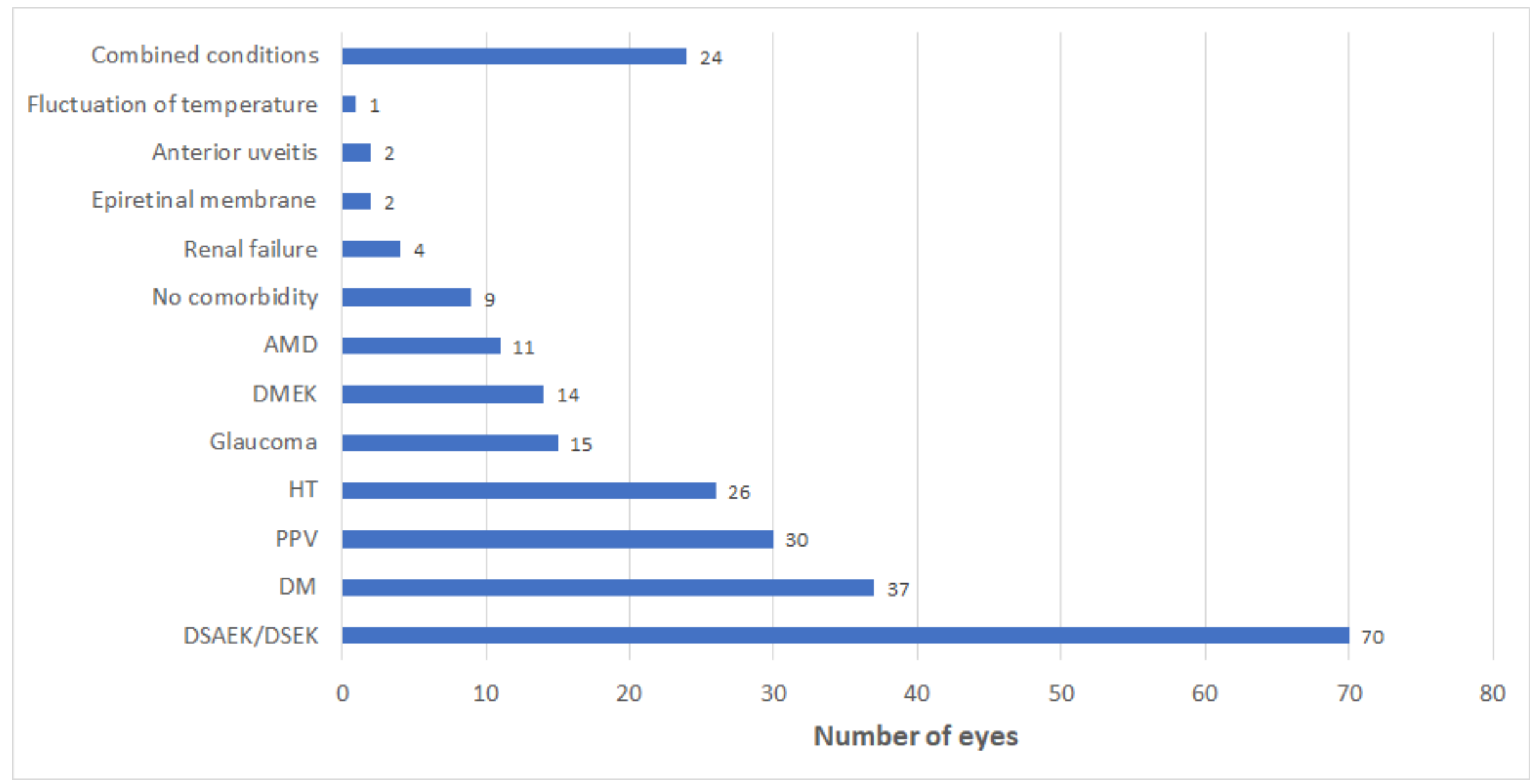

This article is protected by copyright. All rights reserved. 